\title{
The Impact of Chinese FDI on Economic Growth in North Africa
}

\author{
Nsreen Shetewy ${ }^{1 *}$ Li Jun Jiang ${ }^{2 *}$ \\ 1. School of Economics, Jilin University, 2699, Qian Jin Da Jie, Changchun, P. R. China. \\ 2. School of Economics, Jilin University, 2699, Qian Jin Da Jie, Changchun, P. R. China. \\ * E-mail of the corresponding author: nsreen_shetewy@azhar.edu.eg
}

\begin{abstract}
Recently, the eyes of the world have been steadfastly concentrating on the different sources of economic progress in developed and developing countries. This paper aims to examine, the impact of Chinese foreign direct investments (FDI) on economic growth. Using panel data estimation fixed effect on six North Africa countries of the period from 2003 to 2015. The study findings show that Chinese-FDI inflows have no significant impact on economic growth.
\end{abstract}

Keywords: key words, FDI; GDP; Chinese-FDI; random effect \& fixed effect.

DOI: $10.7176 / \mathrm{JPID} / 48-09$

\section{1. . Introduction}

The foreign direct investment (FDI) has turned into the most imperative source of external finance in developing countries (Amendolagine et al., 2019). The significance of this source is clear in the endeavors by numerous from developed and developing countries to attract FDI. Where the majority of developing countries lean toward FDI due to its apparent job in advancing monetary advancement through employment creation, innovation exchange, expanded profitability and financial development (Michael, 2018). Furthermore, FDI is more relative stability other than different sources, also it is low sensitive to economic fluctuations (Kamara, 2013).

Accordingly, in the 1990s, the majority of countries have been facilitating the restrictions towards FDI (Carkovic and Levine, 2005) which is led increase the investments flows of around \$162.9 billion in 1992 (UNCTAD, 1999). Then, these investments have fluctuated until the global crisis, but it recovered and increased markedly in 2017 to $\$ 1.43$ trillion (UNCTAD, 2018).

In context, a theory the endogenous growth models and empirical studies, the paper has focused on the major factors which determinant and promotion of economic growth in North Africa. Therefore, we have generally focused on foreign direct investment (FDI), human capital, trade openness, financial development, inflation, and population.

Although China is considering one of the developing countries, which joined the World Trade Organization in the early 2000s, they have encouraged economic engagement beyond China's territorial borders. The ChineseFDI and trade have risen exponentially in both Africa and Latin America (Narins, 2016). UNCTAD, as shown in Figure 1, indicate that the significant increase in the flow of Chinese FDI to North African countries. Where Chinese-FDI that is increasing at an increasing rate during the period of study. Therefore, the study is a contribution in literature because few studies investigate the impact of FDI flows on economic growth on all North Africa countries at the same time.

United Nations Commission on trade and development (UNCTAD) reported that the flows of Chinese-FDI to North Africa countries also fluctuated between the increase and the decrease. For instance, the value of investments in 2003 started $\$ 5$ billion. In 2005, this number has been increased to $\sim \$ 190$ billion and then by 2012 the FDI has to bake down to $\$ 365$ billion in North Africa. 


\section{Sources; UNCTAD}

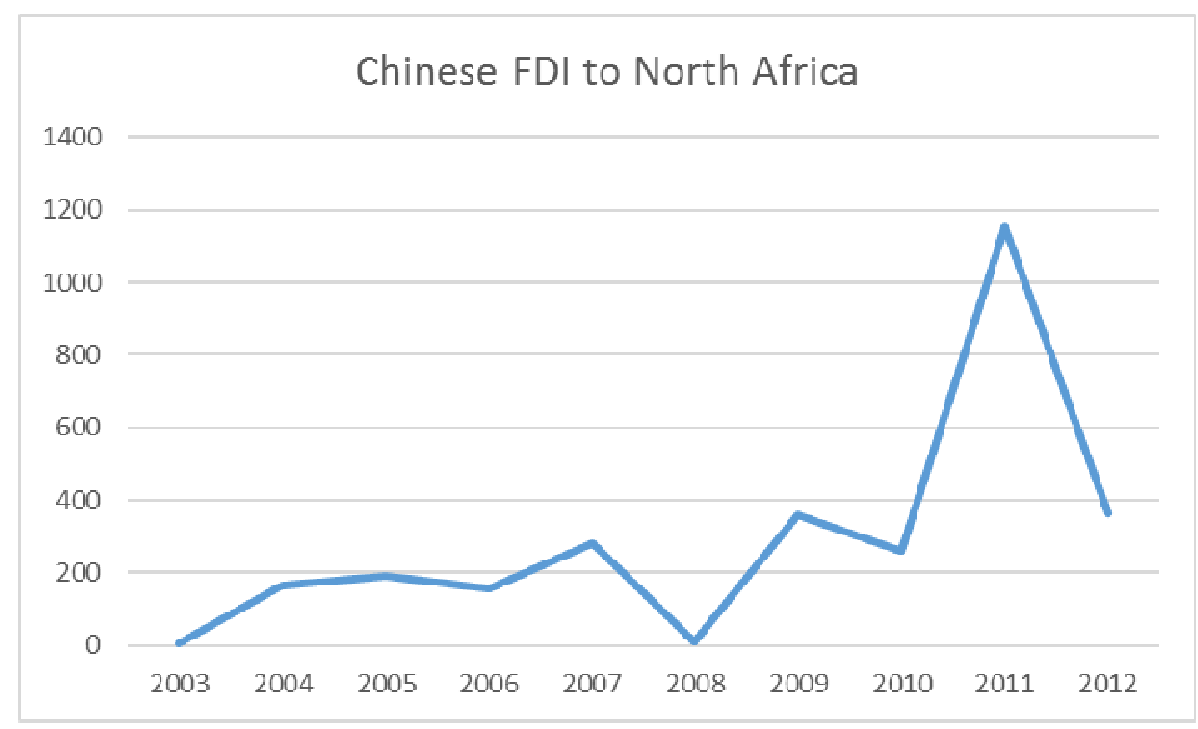

Figure 1. The Chinese-FDI flows to North Africa countries.

Herein, in this paper the impact of Chinese-FDI on economic growth in six Africa countries for the period 2003 to 2015. The studying has been utilized by panel data estimate the fixed effect. We have structured our paper as following: In section 2, the Lecturer review that is divided into positive and negative studies. In section3, the data used have described and presents the specification of the econometric model. In section 4, we show our results; Finally, Section 5 shows conclusion.

\section{Lecturer review}

There is increasing empirical literature that is focused on the relationship between foreign direct investment (FDI) and economic growth. However, still, there is a debate around both positive and negative impact on GDP. This paper examines the effect of foreign direct investment (FDI) on economic growth and determines how the regulatory regime of the countries affects the FDI-growth relationship in 22 sub-Saharan African countries of the period 1980-2011. The findings show that both FDI and regulations do not have an independent significant effect, however, their interaction has a significant positive effect on economic growth. Over the period 1990 and 2008,(Weisbrod and Whalley, 2011) examines the contribution of Chinese-FDI on GDP in sub-Saharan Africa. The result found Chinese-FDI has a positive impact on economic growth.

Similarly, as regards the possibility that Chinese FDI could positively contribute to economic growth in Africa. The results of causality tests shows that the relationship between African GDP and Chinese FDI is bi-directional, while uni-directional relationships were established between Chinese FDI and African infrastructure and corruption, respectively(Claassen et al., 2011).

On the other hand, the results of investigating how Chinese trade, FDI and aid in Africa effect on economic growth in the period from 1991 to 2011. The results indicate there is evidence for displacement effects of African firms due to competition from China (Busse et al., 2016). Addition to, (Kaplinsky et al., 2007) who found Chinese involvement in SSA has a negative effect on commodity-exporting economies, that is destined for domestic and export markets. On the same token, (Eric Evans Osei Opoku, 2018) the study reexamine the impact of FDI on economic growth in Africa relying on panel data from 38 African countries over the period 1960-2014 using GMM method. The paper shows FDI is only significant for the agricultural, service sectors and for most part, is negative for the manufacturing sector albeit insignificantly.

\section{Data and Methodology}

\subsection{Data}

Through the annual data that cover the periods from 2003 to 2015, we have based our work according to the previous economic growth literature to test the impact FDI on economic growth of six North Africa countries. 
Our study has attempted copulated these variables from different resources to estimate the models such as the United Nations Commission on trade and development (UNCTAD) and the World Bank. Firstly, we use GDP as a dependent variable that is the sum of gross value added by all resident producers in the economy plus any product taxes and minus any subsidies not included in the value of the products (World Bank).

Chinese-FDI pointing to direct investment flows to other countries. It is the sum of equity capital, reinvestment of earnings, and other capital. Direct investment is a category of cross-border investment associated with a resident in one economy having control or a significant degree of influence on the management of an enterprise that is resident in another economy (World Bank). Furthermore, some studies have found that growth positively affected by FDI flow. On the other hand, other studies have found FDI flows negative impact on economic growth.

Accordant to the data of human capital, we have used tertiary school enrolment as a measure for human capital. The trade openness has been measured by total imports and exports as proportion GDP. Herein, we use financial development that is domestic credit to the private sector. It is referred to financial resources provided to the private sector by financial corporations, such as through loans, purchases of nonequity securities, and trade credits and other accounts receivable. (World Bank). The inflation is the continuous rise in prices level of goods and services. It knows that inflation is a real signal to status macroeconomic stability in the country or not.

Moreover, the population is about the total counts of all residents regardless of legal status or citizenship. Although, some studies have found that population size could increase productivity, therefore, increase economic growth through the creation of large markets for goods and services (Adams and Opoku, 2015). However, other studies as (Aisen and Veiga, 2013) showed a higher population may be a negative impact on economic growth.

Table 1: Sample countries

\begin{tabular}{|l|l|l|l|l|l|}
\hline \multicolumn{5}{|c|}{ North Africa countries } \\
\hline Algeria & Egypt & Libya & Morocco- & Sudan & Tunisia \\
\hline
\end{tabular}

\subsection{Methodology:}

In this paper, we describe the econometrics model to show the impact of FDI on economic growth in six North African countries. The dynamic panel procedure is utilized for the period from 2003 to 2015 . Furthermore, we have selected Random-Fixed effects estimation for a number of reasons. (I), panel data suggest that countries are heterogeneous. (II), it may be important to incorporate dynamic effects and these models provide a means to study the dynamics of adjustment (Greene, 1997). Where it is important that the models take into consideration possible heterogeneity across countries in order to reduce the risk of obtaining biased estimates. Our empirical model as.

$$
y_{i t}=\alpha_{i}+\beta X_{i t}+\mu_{i t}+v_{i t} \quad(1)
$$

Where $\mathrm{y}$ is GDP in country $\mathrm{i}$ at time $\mathrm{t}, \mathrm{X}$ is a matrix of independent variables (FDI, Human capital, Trade openness, finance development, Inflation and Population) $\alpha$ and $\beta$ are coefficients of the estimate. In addition, $\mu$ it are country specific effects and vit are random errors (Gujarati, 2004).

\section{Empirical Results}

\subsection{Descriptive statistics}

Table 2 depicts the descriptive statistics of different variables in the model as following. It can be seen that the mean-values, standard deviation, minimum and maximum values which explain the values of the highest and lowest observations. On average, the mean value of Chinese-FDI to North Africa countries is around 57.7. Similarly, the average of GDP is 9.39 and SD are 141.9, 7.12 for FDI and GDP respectively. The highest and lowest value of investment flows is 912 and-162. While the Highest and lowest value of trade openness are 1.49and 0.19 . 
Table 2: Descriptive statistics between variables.

\begin{tabular}{|l|l|l|l|l|l|l|l|}
\hline Variable & GDP & FDI & $\begin{array}{l}\text { Human } \\
\text { capital }\end{array}$ & $\begin{array}{l}\text { Trade } \\
\text { openness }\end{array}$ & $\begin{array}{l}\text { Development } \\
\text { finance }\end{array}$ & Inflation & Population \\
\hline Mean & 9.39 & 57.7 & 2.68 & 0.74 & 49 & 6.8 & 3.31 \\
\hline $\begin{array}{l}\text { Std. } \\
\text { Dev }\end{array}$ & 7.12 & 141.9 & 1.28 & 0.29 & 43 & 7.56 & 2.56 \\
\hline $\begin{array}{l}\text { Min } \\
0.47\end{array}$ & & -162 & 0.91 & 0.19 & 6.07 & -4.3 & 32.15 \\
\hline Max & 3.33 & 912 & 8.4 & 1.49 & 3.76 & 36.9 & 9.38 \\
\hline
\end{tabular}

\subsection{Correlation}

The correlation between the variables has found in Table 3. It can be seen the correlation between Chinses -FDI inflow and growth is 0.25 . As well as, the correlation of both human capital and trade openness with economic growth are 0.23 and -0.41 , respectively. Whereas, the correlation between developments finance, inflation, population, and economic growth are a range $(0.77$ to -0.15$)$.

Table 3: Correlation between variables.

\begin{tabular}{|l|l|l|l|l|l|l|l|}
\hline & GDP & $\begin{array}{l}\text { Chinese } \\
- \text { FDI }\end{array}$ & $\begin{array}{l}\text { Human } \\
\text { capital }\end{array}$ & $\begin{array}{l}\text { Trade } \\
\text { openness }\end{array}$ & $\begin{array}{l}\text { Finance } \\
\text { development }\end{array}$ & Inflation & Population \\
\hline GDP & 1.0000 & & & & & & \\
\hline Chinese-FDI & 0.2465 & 1.0000 & & & & & \\
\hline $\begin{array}{l}\text { Human } \\
\text { capital }\end{array}$ & 0.2347 & 0.5012 & 1.0000 & & & & \\
\hline $\begin{array}{l}\text { Trade } \\
\text { openness }\end{array}$ & -0.407 & -0.369 & -0.103 & 1.0000 & & & \\
\hline $\begin{array}{l}\text { Development } \\
\text { finance }\end{array}$ & -0.1514 & 0.108 & 0.164 & -0.1085 & 1.0000 & & \\
\hline \begin{tabular}{l} 
Inflation \\
\hline Population
\end{tabular} & 0.0926 & 0.271 & -0.052 & -0.5551 & 0.111 & 1.0000 & \\
\hline
\end{tabular}

The results of the panel data estimation "fixed effects" were chosen depending on the result of the Hausman test, these results are described in Table 4. Indeed, our main variable is FDI and we found that Chinese-FDI is insignificant effect on economic growth in North Africa countries. This effect happens when we use the main variables that are dependent on the endogenous growth models. Although, the result is not consistent with the theory endogenous growth models. It is consistent with the Solow model and some empirical studies.(Carkovic and Levine, 2005) has found storing evidence of foreign direct investment flows has no independent effect on economic growth.

Moreover, (Angelopoulou and Liargovas, 2014), (Agbloyor et al., 2014) have been shown an impact FDI on economic growth was negative. Also, (Jude and Levieuge, 2017b) is found a forcing direct investment alone has no significant impact on economic growth. Similarly, (Belloumi, 2013) the impact of FDI on economic growth in Tunisia for the period 1970 -2008 has been studded using ARDL approach. The result was missed to confirm any benefit from FDI inflows to Tunisia. The result maybe is because of FDI works on crowding out the local investments. In the same context, probably FDI flows went to investment in serves sectors, not to main sectors that are not doing on the improved productivity in North Africa countries.

Similarly, we have found human capital and trade openness have no significant effect on economic growth. The result is consistent with (Omri and Sassi-Tmar, 2015) which did have the negative impact of trade openness on 
economic growth in North African countries. On the other hand, finance development that is an important matter for increasing economic growth. We found finance development has a positive and significant effect

The estimation coefficient of inflation rate has negative and significant statistically. Where inflation is one-realsignal to a status of macroeconomic stability in the country. The result was confirmed population is a positive and significant impact on growth. The results are consistent with \{Adams, $2015 \# 2\}$, \{Agbloyor, $2014 \# 1$ \} show the population growth drives consumer spending therefore encourage economic activities and production, consequently improve economic growth.

Table 4: Fixed effect estimations (robust standard errors)

\begin{tabular}{|c|c|}
\hline Independent Variables & Fixed Effects \\
\hline Cons & $-3.509^{* * *}$ \\
\hline Chinese-FDI & $\begin{array}{r}-367,19 \\
(1.709)\end{array}$ \\
\hline Human capital & $\begin{array}{l}-0.013 \\
(0.019)\end{array}$ \\
\hline Trade openness & $\begin{array}{l}-8.703 \\
(1.54)\end{array}$ \\
\hline Development finance & $\begin{array}{l}9,179 * * * \\
(909.6)\end{array}$ \\
\hline Inflation & $\begin{array}{l}-7.11 * \\
(3.69)\end{array}$ \\
\hline Population & $\begin{array}{l}13,66 * * * \\
(746.9)\end{array}$ \\
\hline F- Stat & 91,5 \\
\hline Prob.>F & 0.000 \\
\hline R-Squared & 0.89 \\
\hline
\end{tabular}

\section{Conclusion}

This study investigates the impact of Chinese-FDI on six North Africa countries in the period 2003 - 2015. The paper was done based on panel data estimates random and fixed effect estimation, where, panel models allow both the cross-section and the time series aspects of the data in estimates. Addition to, these models are effective to incorporate dynamic effects. Our finding confirmed that Chinese-FDI has no significant impact on economic growth in North Africa countries. Similarly, in our analysis, human capital and trade openness have no significant impact on economic growth. On the other, finance development and population have a positive and significant effect on growth; these are an important tool of encouraging economic activities. There no doubt the inflation rate is the real signal to status macroeconomic stability in the country, here, inflation has a significant and negative effect on GDP. 


\section{References}

Adams, S., E.E.O. Opoku, 2015. Foreign direct investment, regulations and growth in sub-Saharan Africa. Economic Analysis and Policy 47, 48-56.

Agbloyor, E.K., J.Y. Abor, C.K.D. Adjasi, A. Yawson, 2014. Private capital flows and economic growth in Africa: The role of domestic financial markets. Journal of International Financial Markets, Institutions and Money 30, 137-152.

Aisen, A., F.J. Veiga, 2013. How does political instability affect economic growth? European Journal of Political Economy 29, 151-167.

Aitken, B.J., A.E. Harrison, 1999. Do domestic firms benefit from direct foreign investment? Evidence from Venezuela. American economic review 89, 605-618.

Ali, U., J.-J. Wang, 2018. Does Outbound Foreign Direct Investment Crowd Out Domestic Investment in China? Evidence from Time Series Analysis. Global Economic Review, 1-15.

Amendolagine, V., A.F. Presbitero, R. Rabellotti, M. Sanfilippo, 2019. Local sourcing in developing countries: The role of foreign direct investments and global value chains. World Development 113, 73-88.

Angelopoulou, A., P. Liargovas, 2014. Foreign Direct Investment and Growth : EU, EMU and Transition Economies. Journal of Economic Integration 29, 470-495.

Azman-Saini, W., S.H. Law, A.H. Ahmad, 2010. FDI and economic growth: New evidence on the role of financial markets. Economics letters 107, 211-213.

Belloumi, M., 2013. The relationship between trade, FDI and economic growth in Tunisia: An application of the autoregressive distributed lag model.

Cambazoglu, B., H. Simay Karaalp, 2014. Does foreign direct investment affect economic growth? The case of Turkey. International Journal of Social Economics 41, 434-449.

Carkovic, M., R. Levine, 2005. Does foreign direct investment accelerate economic growth? Does foreign direct investment promote development 195.

Claassen, C., E. Loots, H.J.E.R.S.A.W.P. Bezuidenhout, 2011. Chinese foreign direct investment in Africa. 261.

Dutt, A.K., 1997. The pattern of direct foreign investment and economic growth. World Development 25, $1925-$ 1936.

Görg, H., A. Hijzen, 2004. Multinationals and productivity spillovers.

Jude, C., G. Levieuge, 2017a. Growth Effect of Foreign Direct Investment in Developing Economies: The Role of Institutional Quality. The World Economy 40, 715-742.

Jude, C., G. Levieuge, 2017b. Growth Effect of Foreign Direct Investment in Developing Economies: The Role of Institutional Quality. The World Economy 40, 715-742.

Kamara, Y.U., 2013. Foreign Direct Investment and Growth in Sub-Saharan Africa what are the Channels. Available at: www2. ku. edu/ econ/people/documents/Kamara_2013_000. pdf.

Kaplinsky, R., D. McCormick, M. Morris, 2007. The impact of China on sub-Saharan Africa.

Li, X., X. Liu, 2005. Foreign direct investment and economic growth: an increasingly endogenous relationship. World development 33, 393-407.

Liang, F.H., 2017. Does foreign direct investment improve the productivity of domestic firms? Technology spillovers, industry linkages, and firm capabilities. Research Policy 46, 138-159.

Liu, Z., 2008. Foreign direct investment and technology spillovers: Theory and evidence. Journal of Development Economics 85, 176-193.

Malikane, C., P. Chitambara, 2017. Foreign direct investment, productivity and the technology gap in African economies. Journal of African Trade 4, 61-74.

Michael, J., 2018. The effect of foreign aid on foreign direct investment ilnflows: Evidence from Africa.

Narins, T.P., 2016. Evaluating Chinese Economic Engagement in Africa versus Latin America. Geography Compass 10, 283-292.

Nwaogu, U.G., M.J. Ryan, 2015. FDI, foreign aid, remittance and economic growth in developing countries. Review of Development Economics 19, 100-115. 
Omri, A., A. Sassi-Tmar, 2015. Linking FDI inflows to economic growth in North African countries. Journal of the Knowledge Economy 6, 90-104.

Ram, R., K.H. Zhang, 2002. Foreign direct investment and economic growth: Evidence from cross-country data for the 1990s. Economic Development and Cultural Change 51, 205-215.

Smarzynska Javorcik, B., 2004. Does foreign direct investment increase the productivity of domestic firms? In search of spillovers through backward linkages. American economic review 94, 605-627.

UNCTAD, 1999. World investment Report: Infrastructure for developemnt. (United Nations, New York).

UNCTAD, 2015. World Investment Report. p. 43.

UNCTAD, 2018. World Investment Report.

Weisbrod, A., J. Whalley, 2011. The contribution of Chinese FDI to Africa's pre crisis growth surge. (National Bureau of Economic Research).

Wijeweera, A., R. Villano, B. Dollery, 2010. Economic growth and FDI inflows: a stochastic frontier analysis. The Journal of Developing Areas, 143-158. 